\begin{tabular}{|l|l|l||}
\hline \multicolumn{2}{|c|}{ PublisherInfo } \\
\hline \hline PublisherName & $:$ & BioMed Central \\
\hline \hline PublisherLocation & $:$ & London \\
\hline \hline PublisherImprintName & $:$ & BioMed Central \\
\hline \hline
\end{tabular}

\title{
Linked evolution
}

\begin{tabular}{|l|l|l||}
\hline \multicolumn{2}{|c|}{ ArticleInfo } \\
\hline \hline ArticleID & $:$ & 3808 \\
\hline \hline ArticleDOI & $:$ & $10.1186 /$ gb-spotlight-20001023-03 \\
\hline \hline ArticleCitationID & $:$ & spotlight-20001023-03 \\
\hline \hline ArticleSequenceNumber & $:$ & 245 \\
\hline \hline ArticleCategory & $:$ & Research news \\
\hline \hline ArticleFirstPage & $:$ & 1 \\
\hline \hline ArticleLastPage & $:$ & 2 \\
\hline \hline & & RegistrationDate : 2000-10-23 \\
ArticleHistory & $:$ & OnlineDate $\quad$ 2000-10-23 \\
\hline \hline ArticleCopyright & $:$ & BioMed Central Ltd2000 \\
\hline \hline ArticleGrants & $:$ & \\
\hline \hline ArticleContext & $:$ & 130591111 \\
\hline \hline
\end{tabular}




\section{William Wells}

Email: wells@biotext.com

There is more variation in the rate of protein evolution than is expected by chance, although this variation is not caused by slower evolution of essential genes. In the 19 October Nature Williams and Hurst report that one determinant of evolution rates is gene position: the proteins of linked genes evolve at similar rates (Nature 2000, 407:900-903). The major cause of this phenomenon does not seem to be varying concentrations of mutation-sensitive $\mathrm{CpG}$ dinucleotides. The real cause may be the clustering of genes of comparable function, or the variation in recombination frequencies at different chromosomal sites.

\section{References}

1. Mammalian gene evolution: nucleotide sequence divergence between mouse and rat.

2. Do essential genes evolve slowly?

3. Nature, [http://www.nature.com/nature/]

This PDF file was created after publication. 